\title{
THE ROLE OF CHROMOSOME ANALYSIS IN MALE AND FEMALE INFERTILITY
}

\author{
Kromozom Analizinin Erkek ve Kadın Infertilitesindeki Yeri
}

\author{
Burhan BALTA $^{1}$ (D), Murat ERDOĞAN ${ }^{1}$ (D), Aslıhan KİRAZ ${ }^{1}$ iD, Gökhan SÖNMEZ ${ }^{1}$ iD
}

${ }^{1}$ Kayseri Şehir Hastanesi, Tıbbi Genetik Kliniği, KAYSERİ, TÜRKIYYE

\section{ABSTRACT}

ÖZ

Objective: Infertility is defined as absence of a healthy baby or pregnancy despite a one-year regular unprotected sexual intercourse. While primary infertility is called the absence of pregnancy at all, secondary infertility is called inability of couples who have had at least one healthy child to become pregnant. Chromosome anomalies are an important cause of both male and female infertility. In this study, we aimed to discuss the results of chromosome analysis of couples with primary infertility.

Material and Methods: A total of 535 people, 262 women and 273 spouses with primary infertility, were included in the study. Chromosome analysis was performed using standard cytogenetic GTG banding technique using peripheral blood lymphocytes.

Results: Normal chromosome establishment was detected in 513 people, 46, XX in 254 people, 46, XY in 259 people (95.8\%). Eight patients had a normal chromosome variant $(1.4 \%)$. In addition, translocation was detected in 5 patients $(0.8 \%)$; in 4 patients, balanced reciprocal translocation and in 1 patient, Robertsonian translocation. Klinefelter syndrome was detected in 3 patients ( $1 \%$ of male infertility). In addition, we detected Turner syndrome variants, mos 45,X[11]/46,XX,i $(\mathrm{X})(\mathrm{q} 10)[29]$ and $\operatorname{mos} 45, \mathrm{X}[10] / 46, \mathrm{X}, \mathrm{i}(\mathrm{X})(\mathrm{q} 10)[10](0.7 \%$ of female infertility) in two cases. If normal chromosome variants are excluded, the frequency of the remaining changes in the patient population is $2.6 \%$.

Conclusion: Structural chromosomal anomalies such as balanced reciprocal and Robertsonian translocations cause both female and male infertility. 47,XXY should be kept in mind for male infertility and 45,X/46,X,i(X)(q10) Turner chromosome variants should be kept in mind in female infertility. In summary, chromosome analysis is one of the important tests that should be done to explain the etiology of both male and female infertility.

Keywords: Infertility, translocation, chromosome analysis, reciprocal, Klinefelter syndrome
Amaç: İnfertilite, bir yıllık düzenli korunmasız ilişkiye rağmen gebelik ve sağlıklı bebek oluşmamasına denir. Birincil infertilite, gebeliğin hiç elde edilememesine denilirken, ikincil infertilite ise daha önce sağlıklı en az bir çocuk sahibi olmuş çiftlerin gebe kalamaması olarak adlandırılır. Kromozom anomalileri hem erkek hem de kadın infertilitesinin önemli bir nedenidir. Biz bu çalışmada birincil infertilitesi olan çiftlerin kromozom analizi sonuçlarını tartışmayı amaçladık.

Gereç ve Yöntemler: Birincil infertilitesi olan 262 kadın ve 273 erkek toplam 535 kişi çalışmaya dahil edildi. Kromozom analizi periferal kan lenfositleri kullanılarak standart sitogenetik GTG bantlama tekniği kullanılarak yapıldı.

Bulgular: İki yüz elli dört kişide 46,XX, 259 kişide 46,XY olmak üzere toplam 513 kişide normal kromozom kuruluşu tespit edildi $(\% 95,8)$. Sekiz hastada normal kromozom varyantı tespit edildi $(\% 1,4)$. Bunun yanında 4 hastada dengeli resiprokal translokasyon, 1 hastada ise Robertsoniyan translokasyon olmak üzere 5 hastada translokasyon tespit edildi (\%0.8). Üç hastada Klinefelter sendromu tespit edildi (erkek infertilitesinin $\% 1$ 'i). Ayrica 2 hastada Turner sendromu varyant olan mos 45,X[11]/46,XX,i(X)(q10)[29] ve $\operatorname{mos} 45$, $\mathrm{X}[10] / 46, \mathrm{X}, \mathrm{i}(\mathrm{X})(\mathrm{q} 10)[10] \quad($ kadın infertilitesinin \%0.7'si) saptandı. Normal kromozom varyantlarını dışlandığında geri kalan değişimlerin hasta popülasyonunda sıklığı \%2.6 olarak bulundu.

Sonuç: Dengeli resiprokal ve Robertsoniyan translokasyonlar gibi yapısal kromozom anomalileri hem kadın hem de erkek infertilitesine neden olurlar. 47,XXY erkek infertilitesinde, $45, X / 46, X, i(X)(q 10)$ Turner kromozom varyantları kadın infertilitesinde akılda tutulmalıdır. Özetle kromozom analizi hem kadın hem de erkek infertilite etiyolojisini açıklamak adına yapılması gereken önemli testlerden biridir.

Anahtar Kelimeler: Infertilite, translokasyon, kromozom analizi, resiprokal, Klinefelter sendromu 


\section{INTRODUCTION}

Infertility is defined as the inability to achieve pregnancy in one year despite regular and unprotected sexual intercourse. The absence of pregnancy is called primary infertility, while the inability of couples who have had healthy children before to achieve pregnancy is called secondary infertility (1). Infertility is seen in $15 \%$ of couples in reproductive age (2) .

Chromosome anomalies are an important cause of both male and female infertility. Chromosomal disorders have been found in $2-8 \%$ of infertile men (3). In addition to major chromosome abnormalities such as Klinefelter syndrome, 47,XYY syndrome, reciprocal translocations, Robertsonian translocations and inversions, micro deletions in the AZF regions (AZFa, $\mathrm{AZFb}$ and $\mathrm{AZFc}$ ) on the $\mathrm{Y}$ chromosome have also been associated with male infertility (4). Klinefelter syndrome is the most common chromosome abnormality causing male infertility which is characterized by small testicle, hypogonadotropic hypogonadism induced gynecomastia and virilization deficiency, azoospermia due to impaired spermatogenesis, infertility and tall stature (5-7). Its population incidence is about 1-2/1000. 47,XYY syndrome is generally fertile. However, when compared with normal 46,XY karyotype, infertility is relatively more common.

Female infertility, on the other hand is more complicated than male infertility and it involves many different elements. For a woman to become pregnant, she needs a regular ovulation, healthy uterus, endometrium and fallopian tubes and regular hormonal values. Chromosomal disorders can affect each of these separately or several of these simultaneously. 47, XXX syndrome is known to cause premature ovarian syndrome by disrupting ovulation (8). The increase in the number of triple repeats expansion in FMR1 gene cause premature ovarian deficiency (9). Turner syndrome is the most common sex chromosome abnormality in women. Its incidence is $1 / 2500$. Turner syndrome can cause infertility by disrupting both anatomical structure, hormonal balance, and the order of ovulation (10). Phenotype may be milder in mosaic Turner syndrome patients. Moreover, individuals with mosaic Turner syndrome can conceive spontaneously and have healthy children (11). Nevertheless, this mosaicism results in rapid ovarian deficiency and secondary infertility (12). Apart from these, 46,XX male phenotypic or 46,XY female phenotypic sex developmental disorders are among the rare causes of infertility.

Reciprocal, Robertsonian translocations, inversion, deletion, and duplications are called structural chromosome anomalies. Balanced chromosomal translocations are called displacement of genetic material without any loss of part between the two chromosomes. Translocations between chromosomes $13,14,15,21$ and 22 , in other words acrocentric chromosomes, are called Robertsonian type translocation. Reciprocal chromosome part exchanges other than these translocations are called reciprocal translocation. Most balanced chromosomal carrier individuals are phenotypically normal if the fracture site does not pass over an important gene (13). However, they can cause infertility by disrupting spermatogenesis and causing meiotic pause (14).

In this study, we aimed to discuss the karyotype results of couples who referred with primary infertility in Central Anatolia region and the relationship of these results with infertility.

\section{MATERIALS AND METHODS}

Couples who could not achieve pregnancy despite oneyear long unprotected sexual intercourse and who applied to Kayseri Training and Research Hospital Medical Genetic Clinic between January 2013 and November 2018 were included retrospectively in this 
study. Secondary infertility cases were excluded from the study. A total of 535 individuals, 262 females and 273 males, were included in the study. Age, gender and chromosome analysis results were noted retrospectively. This study was carried out according to the Declaration of Helsinki and Good Clinical Practices Guidelines with the 2019/63 numbered approval of Erciyes University Ethics Committee of Clinical Research (Date: 23.01.2019, issue no: 2019/63). Signed consent form was taken from all the participants in the study.

\section{Chromosome Analysis}

Chromosome analysis was performed with patients' peripheral blood lymphocytes by using standard cytogenetic GTG banding technique. Seventy-two hours of culture was performed using periferal blood lymphocytes. KaryoMAX Colcemid Solution (Gibco) was added at the 70th hour to stop the chromosomes at the metaphases stage. $0.075 \mathrm{M} \mathrm{KCl}$ was used as a hypotonic agent and the fixative formed by adding 1part acetic acid to 3 parts methanol was used for harvesting stage. Metaphase preparations obtained after the culture were stained using the Giemsa-TrypsinGiemsa (GTG) banding method. At least 20 metaphase areas from each patient were evaluated microscopically. However, in unusual chromosome structures, number of metaphases was increased up to 40 . Ten of these were karyotyped and evaluated with Cytovision (Applied Imaging). All metaphases were examined in terms of numerical and structural chromosome anomalies. Karyotype results were recorded according to International System for Human Cytogenetic Nomenclature (ISCN,2009).

\section{Statistical Analysis}

Statistical analyses were performed using the Statistical Package for Social Sciences (SPSS. Inc. Chicago. Illinois. USA) 23.0 for Windows. The descriptive statistics was performed. The results were given as $n$, percent, and mean \pm standard deviation (SD). The $\mathrm{p}<0.05$ was accepted as statistically significant.

\section{RESULTS}

Chromosome analysis was performed on 535 patients who could not achieve pregnancy despite one year long unprotected sexual intercourse. Mean age of the participants was $30.9 \pm 6.0$ years. Mean age of the women in the study was $29.2 \pm 5.8$ years, while mean age of the men in the study was $32.5 \pm 5.8$ years. Normal chromosome structure 46,XX $(254 / 262,96.9 \%)$ or $46, \mathrm{XY}(259 / 273,94.8 \%)$ was found in 513 participants. Chromosome anomaly was found in $4.1 \%$ (22/535) of all patients. While this rate was $5.1 \%$ (14/273) in men, and 3\% (8/262) in women. Normal chromosome variant was found in 8 patients (1.4\% of all patients). In addition, balanced reciprocal translocation was found in 4 patients $(3 / 273,1 \%$ of male infertility; $1 / 262,0.4 \%$ of female infertility), while Robertsonian translocation was found in 1 patient $(1 / 262,0.4 \%$ of female infertility). Klinefelter syndrome was found in 3 patients $(3 / 273,1 \%$ of male infertility). In addition, Turner syndrome mos 45,X[11]/46,XX,i(X)(q10)[29] and mos $45, X[10] / 46, X, i(X)(q 10)[10](2 / 262,0.7 \%$ of female infertility) was found in 2 patients. If we consider normal chromosome variants as normal, the incidence of the remaining changes in patient population is $2.6 \%$. Table 1 shows the classification of chromosome anomalies and percentage distributions found in female and male infertility in detail. Table 2 lists results of structural and numerical chromosomal analysis and Table 3 lists normal chromosome variants considered as polymorphism that found in male and female infertility.

As a result, Klinefelter syndrome and reciprocal translocations were the most frequent reason of infertility in men. Mosaic Turner syndrome variants were the most common reason in women. 
Table 1: The results of structural and numerical chromosomal analysis that detected in men with primary infertility

\begin{tabular}{lc}
\hline Karyotypes & Number \\
\hline $45, \mathrm{X}[2] / 46, \mathrm{XY}[18]$ & 1 \\
$46, \mathrm{XY}, \mathrm{t}(10 ; 22)(\mathrm{q} 11 ; \mathrm{p} 12)$ & 1 \\
$46, \mathrm{XY}, \mathrm{t}(1 ; 9)(\mathrm{q} 21.1 ; \mathrm{q} 34.1)$ & 1 \\
$46, \mathrm{XY}, \mathrm{t}(7 ; 15)(\mathrm{p} 11.2 ; \mathrm{q} 26.2)$ & 1 \\
$45, \mathrm{X}[9] / 46, \mathrm{XY}[11]$ & 1 \\
$46, \mathrm{XY}, 1 \mathrm{qh}+$ & 1 \\
$46, \mathrm{XY}, 14 \mathrm{ps}+$ & 2 \\
$46, \mathrm{XY}$, inv $(9)(\mathrm{p} 12 \mathrm{q} 13)$ & 3 \\
$47, \mathrm{XXY}$ & 3 \\
$46, \mathrm{XY}$ & 259 \\
Sum & 273 \\
\hline
\end{tabular}

Table 2: The results of structural and numerical chromosomal analysis that detected in women with primary infertility

\begin{tabular}{lc}
\hline Karyotypes & Number \\
\hline $\operatorname{mos} 45, \mathrm{X}[11] / 46, \mathrm{X}, \mathrm{i}(\mathrm{X})(\mathrm{q} 10)[29]$ & 1 \\
$\operatorname{mos} 45, \mathrm{X}[10] / 46, \mathrm{X}, \mathrm{i}(\mathrm{X})(\mathrm{q} 10)[10]$ & 1 \\
$45, \mathrm{X}[2] / 46, \mathrm{XX}[38]$ & 1 \\
$46, \mathrm{XX}, \mathrm{t}(1 ; 7)(\mathrm{p} 13 ; \mathrm{p} 13)$ & 1 \\
$45, \mathrm{XX}, \mathrm{t}(13 ; 14)(\mathrm{q} 10 ; \mathrm{q} 10)$ & 1 \\
$46, \mathrm{XX}, 9 \mathrm{qh}+$ & 3 \\
$46, \mathrm{XX}$ & 254 \\
Sum & 262 \\
\hline
\end{tabular}

Table 3: Normal chromosome variants considered as polymorphism

\begin{tabular}{ll}
\hline Chromosomal Karyotype & Number \\
\hline $46, \mathrm{XY}, \operatorname{inv}(9)(\mathrm{p} 12 \mathrm{q} 13)$ & 3 \\
$46, \mathrm{XX}, 9 \mathrm{qh}+$ & 2 \\
$46, \mathrm{XY}, 14 \mathrm{ps}+$ & 2 \\
$46, \mathrm{XY}, 1 \mathrm{qh}+$ & 1 \\
Sum & 8 \\
\hline
\end{tabular}

\section{DISCUSSION}

In this study, the rate of chromosome anomaly was found higher in men $(14 / 273,5 \%)$ when compared with women $(8 / 262,3 \%)$. In our study, Klinefelter syndrome was found in 3 patients. Klinefelter syndrome was the most common reason of male infertility (1\%). This result was in parallel with the literature $(15,16)$. However, 47,XYY syndrome was not found in our study. Rapidly advancing assisted reproduction methods have become hope for Klinefelter syndrome today. Ramasamy et al. received sperm with microscopic testicular sperm extraction from 45 of 68 non-mosaic Klinefelter patients $(66.2 \%)$ and with the help of in vitro fertilization, they achieved pregnancy that could live in $45 \%$ of these (17). In a study conducted on Korean population, Kim et al. reported that the probability of chromosome anomaly was much higher in patients with male factor, that is, sperm number and structure anomaly such as azoospermia, oligospermia, oligoteratospermia (18). In the studies of Karaer et al. and Yalçintepe from Turkey, they found the rate of chromosomal abnormality as $11 \%$ in primary infertile patients, which supports Korean study $(19,20)$.

Although they are phenotypically normal, balanced translocation carrier individuals can have problems such as decreased fertility, spontaneous miscarriage, or dysmorphic babies (13). The probability of structural chromosomal anomaly has been reported as $5 \%$ in infertile men (21). The reason for the decrease in the fertility of translocation carrier individuals results from problems in forming "quadrivalent or trivalent" structures of chromosomal translocations during meiosis and obtaining homologous chromosomes. In their meiotic segregation study, Morel et al. reported reciprocal translocation carrier men to have a chromosomal unbalanced spermatozoa transport rate between $19 \%$ and $80 \%(22)$. 
In our study, when male and female patients were considered together, the most important cause of infertility resulting from chromosome analysis was chromosomal translocations (number=5; 0.9\%). In Liu et al.'s study, this rate was reported as $1.36 \%(15)$. In the study of Gumus from Turkey, this rate was $0.8 \%$ (1/120)

In addition, in men, translocations between $\mathrm{X}$; autosomal or Y; autosomal chromosomes have been reported to cause azoospermia and infertility by disrupting the spermatogenesis of translocations $(24,25)$. In women, the location of the fracture is important in $\mathrm{X}$; autosome chromosome translocations. Regions between Xp11.1 and Xp21 and Xq13-q26 are important for normal ovarian function and the fractures passing from here cause premature ovarian deficiency (26). In addition, when the segregation pattern of female Robertsonian translocation carriers is examined, it was found that the rate of obtaining viable embryos was lower than that of men (27). In our study, X;autosomal or Y;autosomal translocation was not found in men or women.

$1 \mathrm{qh}+, 9 \mathrm{qh}+, 16 \mathrm{qh}+, 13 \mathrm{ps}+, 13 \mathrm{pstk}+, 22 \mathrm{ps}+$, which are considered as normal chromosome variant, are benign chromosome variants not associated with any health problems $(28,29)$. Eight (1.4\%) chromosome variants were found in our study. In the study of Gumus from Turkey, the rate of chromosomal polymorphism was $5.8 \%$ in patients with primary infertility (23). Although it has been previously claimed that this normal chromosome variants may be associated with infertility, there are no convincing studies in this regard (30).

45,X Turner syndrome was not found in our study. However, 3 variants of Turner were found and 2 of these were $45, X / 46, X, i(X) q 10$ Turner variants. The rate of Turner variants was $1.1 \%$ within the female infertile group. In Riccaboni et al.'s study, the rate of gender chromosome mosaicism in female infertility was $0.5 \%$ (31). Turner syndrome patients very likely have the risk of primary ovarian deficiency and infertility. 45,X/46,XX mosaic Turner syndrome can have primordial follicular pool sufficient for menarche and normal pubertal development (32). However, these women can develop premature ovarian deficiency very quickly when compared with normal 46,XX women $(33,34)$. Isochromosome $\mathrm{X}$, mosaic Turner syndrome, which is a variant of Turner, causes a more moderate phenotype. These patients should be evaluated case by case and the development of internal genital organs such as uterus and ovaries and menstrual condition should be checked. Some of the Turner syndrome patients can have pregnancy. Especially individuals with mosaic Turner syndrome can get pregnant and have healthy children (11). Pregnancy has been reported previously in literature for isochromosome X. However, some of the patients experience problems such as pregnancy loss, gestational diabetes and cardiac anomalies even if they have pregnancy.

In addition, new generation sequencing method should be mentioned in the diagnosis of chromosomal diseases. With the whole genome analysis by using new generation sequencing method, balanced translocations and inversions can be diagnosed $(35,36)$. In the near future, it will probably be possible to diagnose both cytogenetic anomalies and single gene diseases in genetic diagnosis laboratories with a single whole genome analysis. Even in this case, confirmation with GTG banding will be required. Therefore, the fact that chromosome analysis and GTG banding method provide the opportunity to see the chromosomes visually shows that they are still indispensable in the diagnosis of these diseases.

One handicap of this study is the relatively low number of patients. For this reason, X;autosomal, Y;autosomal translocations, gender development anomalies and 47,XYY syndrome which are associated with infertility in literature were not found in this study. 
As a conclusion, structural chromosome anomalies such as balanced reciprocal and Robertsonian translocations cause both female and male infertility. 47,XXY should be kept in mind in male infertility, while 45,X/46,X,i(X)(q10) Turner chromosome variants should be kept in mind in female infertility. In summary, despite rapidly developing new generation sequencing methods and algorithms, chromosome analysis is one of the important tests that should be performed to explain the etiology of both female and male infertility.

Conflict of Interest: The authors declare that they have no conflict of interest.

Support and Acknowledgment: There is no funding source.

Researchers' Contribution: Design: B.B.; Data Collection: B.B., M.E., A.K.; Genetic Analysis: B.B., M.E., A.K.; Urological Examination: G.S.; Literature Search: A.K.; Writing: B.B., M.E., A.K.

Ethics Committe Aproval: Erciyes University Ethics Committee of Clinical Research, date:23.01.2019, issue number: 2019/63.

\section{REFERENCES}

1. Tabong PTN, Adongo PB. Infertility and childlessness: A qualitative study of the experiences of infertile couples in Northern Ghana. BMC Pregnancy and Childbirth. 2013;13:1-10.

2. Matzuk MM, Lamb DJ. Genetic dissection of mammalian fertility pathways. Nat Cell Biol. 2002;4(1):41-9.

3. Ferlin A, Raicu F, Gatta V, Zuccarello D, Palka G, Foresta C. Male infertility: Role of genetic background. Reprod Biomed Online. 2007;14(6):734-45.
4. Vogt PH. Human chromosome deletions in Yq11, AZF candidate genes and male infertility: History and update. Mol Hum Reprod. 1998;4(8):739-44.

5. Punab M, Poolamets O, Paju P, Vihljajev V, Pomm K, Ladva R et al. Causes of male infertility: A 9-year prospective monocentre study on 1737 patients with reduced total sperm counts. Hum Reprod. 2017;32(1):18-31.

6. Krausz C, Riera-Escamilla A. Genetics of male infertility. Nat Rev Urol. 2018;15(6):369-84.

7. Stouffs K, Seneca S, Lissens W. Genetic causes of male infertility. Ann Endocrinol (Paris). 2014;75(2):109-11.

8. Rafique M, AlObaid S, Al-Jaroudi D. 47, XXX syndrome with infertility, premature ovarian insufficiency, and streak ovaries. Clin Case Rep. 2019;7(6):1238-41.

9. Sherman SL. Premature ovarian failure in the fragile X syndrome. Am J Med Genet. 2000;97(3):189-94.

10. Gravholt $\mathrm{CH}$. Clinical practice in Turner syndrome. Nat Clin Pract Endocrinol Metab. 2005;1(1):41-52.

11. Bernard V, Donadille B, Zenaty D, Courtillot C, Salenave S, Brac De La Perrière A et al. Spontaneous fertility and pregnancy outcomes amongst 480 women with Turner syndrome. Hum Reprod. 2016;31(4):782-8.

12. Simpson JL, Rajkovic A. Ovarian differentiation and gonadal failure. Am J Med Genet. 1999;89(4):186200.

13. Harton GL, Tempest HG. Chromosomal disorders and male infertility. Asian J Androl. 2012;14(1):329.

14. Hann MC, Lau PE, Tempest HG. Meiotic recombination and male infertility: from basic science to clinical reality? Asian J Androl. $2011 ; 13(2): 212-8$. 
15. Liu Y, Kong XD, Wu QH, Li G, Song L, Sun YP. Karyotype analysis in large-sample infertile couples living in Central China: a study of 14965 couples. J Assist Reprod Genet. 2013;30(4):547-53.

16. Lanfranco F, Kamischke A, Zitzmann M, Nieschlag PE. Klinefelter's syndrome. Lancet. 2004;364(9430):273-83.

17. Ranjith R, A RJ, D PG, Veeck GL, Zev R, N SP. Successful Fertility Treatment for Klinefelter's Syndrome. J Urol. 2009;182(3):1551-3.

18. Kim MJ, Choi HW, Park SY, Song IO, Seo JT, Lee HS. Molecular and cytogenetic studies of 101 infertile men with microdeletions of y chromosome in 1, 306 infertile Korean men. J Assist Reprod Genet. 2012;29(6):539-46.

19. Yalçıntepe S, Eker D, Gürkan H. Trakya bölgesi erkek infertilite olgularında y kromozom mikrodelesyonları ve sitogenetik anomalilerin sıklığı: Tek merkez deneyimi. İstanbul Tıp Fakültesi Dergisi. 2021;84(1):27-33.

20. Karaer D, Şahinoğlu B, Gürler A, Karaer K. İnfertil erkek hastalarda karyotip analizi ve Y kromozom mikrodelesyon analiz sonuçları. Pamukkale Medical Journal. 2021;14(3):620-5.

21. O’Flynn O’Brien KL, Varghese AC, Agarwal A. The genetic causes of male factor infertility: A review. Fertil Steril. 2010;93(1):1-12.

22. Morel F, Douet-Guilbert N, le Bris MJ, Herry A, Amice V, Amice $\mathrm{J}$ et al. Meiotic segregation of translocations during male gametogenesis. Int $\mathrm{J}$ Androl. 2004;27(4):200-12.

23. Gümüş E. Evaluation of chromosomal anomalies and polymorphisms in primer infertility, Azospermia and Habitual Abortion Patient Groups. Van Med J. 2019;26(1):12-7.

24. Ishikawa T, Kondo $\mathrm{Y}$, Yamaguchi K, Oba T, Sakamoto Y, Takenaka A et al. An unusual reciprocal X-autosome translocation in an infertile azoospermic man. Fertil Steril. 2007;88(3):15-7.

25. Dundar M, Balta B, Bahadir O, Acar H, Baydilli N, Baltaci $\mathrm{V}$ et al. An uncommon cause of infertility: Y;1 translocation and PGD trial. Genet Couns. 2014;25(3):353-5.

26. Krauss CM, Turksoy RN, Atkins L, McLaughlin C, Brown LG, Page DC. Familial premature ovarian failure due to an interstitial deletion of the long arm of the $\mathrm{x}$ chromosome. $\mathrm{N}$ Engl $\mathrm{J}$ Med. 1987;317(3):125-31.

27. Ko DS, Cho JW, Lee HS, Kim JY, Kang IS, Yang KM et al. Preimplantation genetic diagnosis outcomes and meiotic segregation analysis of robertsonian translocation carriers. Fertil Steril. 2013;99(5):1369-76.

28. Nielsen J, Friedrich U, Hreidarsson ÁB. Frequency and genetic effect of $1 \mathrm{qh}+$. Humangenetic. 1974;21(2):193-6.

29. Gardner RJM, Sutherland GR, Shaffer LG. Chromosome Abnormalities and Genetic Counseling. Oxford, UK. Oxford University Press, 2012.

30. Dana M, Stoian V. Association of pericentric inversion of chromosome 9 and infertility in romanian population. Maedica (Bucur). 2012;7(1):28-9.

31. Riccaboni A, Lalatta F, Caliari I, Bonetti S, Somigliana E, Ragni G. Genetic screening in 2,710 infertile candidate couples for assisted reproductive techniques: results of application of Italian guidelines for the appropriate use of genetic tests. Fertil Steril. 2008;89(4):800-8.

32. Pasquino AM, Passeri F, Pucarelli I, Segni M, Municchi G. Spontaneous pubertal development in Turner's syndrome. J Clin Endocrinol Metab. 1997;82(6):1810-3. 
33. Reindollar RH. Turner syndrome: contemporary thoughts and reproductive issues. Semin Reprod Med. 2011;29(4):342-52.

34. Oktay K, Bedoschi G, Berkowitz K, Bronson R, Kashani B, McGovern P et al. Fertility preservation in women with Turner Syndrome: A comprehensive review and practical guidelines. J Pediatr Adolesc Gynecol. 2016;29(5):409-16.

35. Liang D, Wang Y, Ji X, Hu H, Zhang J, Meng L et al. Clinical application of whole-genome lowcoverage next-generation sequencing to detect and characterize balanced chromosomal translocations. Clin Genet. 2017;91(4):605-10.

36. Dong Z, Yan J, Xu F, Yuan J, Jiang H, Wang H et al. Genome sequencing explores complexity of chromosomal abnormalities in recurrent miscarriage. Am J Hum Genet. 2019;105(6):110211. 